\title{
Research on Resettlement and Resettlement of Water Conservancy
}

\section{Projects}

\author{
Rao Xiong ${ }^{1, a}$, Xue Hui ${ }^{2, b}$ \\ 13700 Walnut Street Philadephia, PA 19104.USA \\ ${ }^{2}$ No.9 Cultural Road, Jiangxia District, Wuhan, China \\ axiongrao0716@outlook.com, bxuehui0423@QQ.com
}

Keywords: Water conservancy project, resettlement, compensation.

Abstract.Water conservancy project is a system engineering, including rural town, city and county, and many aspects of industrial and mining enterprises and special facilities. The resettlement work involving many points, wide, long, is the focus and difficulty in the implementation of the water conservancy project, but also the social stability and development evaluation index.

\section{Introduction}

Water conservancy project occupies a very important position in the development of the society. China has built all kinds of reservoir nearly one hundred thousand, and south to North Water Diversion Project, water diversion and other large northern Hubei diversion project. Water conservancy project scale and quantity among the forefront of the world. The large water conservancy construction can improve people's livelihood, affect the ecological environment and climate, natural disaster reduction the loss and stimulate the economy, has great economic benefit and social benefit, but also will cause the engineering occupation personnel within the scope of the submerged migration. This paper describes in detail the evaluation principle and implementation plan of water conservancy resettlement compensation.

\section{Resettlement project status}

\section{Research status at home and abroad}

There are many international experts and scholars have studied deeply on immigration project such as: M Michael (1998) wrote "immigrants. Reconstruction. Development" (2003), Ravi Kanbur wrote "the development of economics and the principle of compensation", the resettlement compensation problem, investment and benefit, policy and social problems to do an in-depth analysis and research, has certain directive significance to the resettlement project.

There are also many domestic experts and scholars have unique insights on resettlement such as: Shi Guoqing (1996), author of "the reservoir immigrant life level analysis and evaluation methods", Jiao Aiping (2006) author of "water conservancy project production and living standard of resettlement monitoring and evaluation index system research", has an important guiding significance for the resettlement project.

\section{Basis and connotation of resettlement compensation}

\section{principle and basis of compensation}

a. according to the relevant laws, regulations and rules and regulations; 
b. Based on the investigation results and the resettlement planning results of land acquisition and resettlement;

c. the impact of immigration on the local social economy.

\section{compensation of the project division}

a. the project includes: rural, urban (set) town, industrial enterprises, professional projects, other costs, as well as preparatory fees, taxes and fees, etc..

b. professional project: including transportation, power, telecommunications, radio and television, all kinds of pipe, water conservancy and Hydro-power Engineering, should adopt measures, usually related to professional standards and quota calculation, analysis and calculation of compensation cost or adopt analogy integrated unit index were analyzed to develop.

c. land acquisition, in accordance with the original use of the land to be compensated, the land compensation and resettlement subsidies, should meet the needs of rural resettlement funds. Use of other units or individuals in accordance with the law of the use of state-owned land, in accordance with the standard of compensation for the expropriation of farmland for compensation, the use of state-owned land is not determined to be used by units or individuals, not to compensate.

d. the land is attached to the building, in accordance with the original size, the original standard or restore the original function of the principle of compensation, the compensation fee is not sufficient to build the basic use of the room to give appropriate subsidies to immigrants.

e. resettlement compensation investment estimate, according to the estimate in the same year in floodway policy and price level of preparation.

f. the investment of land expropriation resettlement is determined according to the progress of resettlement in different years.

\section{Cost estimates for resettlement compensation}

price level in the same period in accordance with the main project price level. compensation for rural migrant workers

Compensation standard land compensation and resettlement subsidies

a. Determination of the output value of arable land: including paddy fields, dry land, vegetable fields, orchards, Lin Yuan, fish ponds and so on

b. crop compensation

Crop compensation compensation of land by single season earnings, including paddy field, dry land, vegetable fields, orchards and ponds.

c. compensation for housing and accessories

According to the housing design data and the relevant construction quota, the paper analyzes the amount of material used in various building houses, and calculates the replacement cost of houses according to the method of budget estimate. The compensation fee for the compensation shall be based on the investigation and analysis of the project, and the compensation price shall be determined in accordance with the relevant local demolition compensation method.

d. migration

Migration and relocation expenses, including transportation, transportation, accommodation, materials handling, removal of insurance premiums, the loss of material subsidies, loss of work allowance and temporary housing subsidies.

e. transitional living allowance

In order to ensure the stability of immigrants in the production process of life, to the resettlement of a certain living allowance, according to a certain amount of compensation per person per month. 


\section{f. infrastructure costs}

Centralized relocation of infrastructure construction costs, including the construction land acquisition fee, land leveling fees, road engineering fees, water supply and drainage engineering fees, power engineering fees, radio and television engineering fees. Based on the calculation of the typical residential design and the related unit price.

Scattered housing infrastructure construction costs per capita investment in residential development projections.

Compensation standards for infrastructure construction: according to the per capita cost of rural areas, the per capita cost of the city and the per capita cost of the city.

Relocation costs, transitional living allowance, infrastructure construction fees.

g. housing subsidies for poor families: $15 \mathrm{~m} 2$ per capita less than the main room of brick and concrete compensation for the resettlement of households, subsidies difference. This report is not yet listed.

h. compensation sidelines and individual industrial and commercial households and businesses

Compensation fee includes the cost of field leveling, housing compensation, relocation subsidies, equipment compensation, facilities compensation, loss of production costs, etc..

i. temporary land compensation fee

2 years of temporary land compensation. Among them, the difference between the compensation of the land and the compensation for the land and the compensation of the fish pond and the pond in the intensive farming pond.

j. temporary land reclamation investment

According to the relevant local regulations and the specific circumstances of the project, the temporary land reclamation investment. Including: pond filling solid base area (pond, pond), soil material area, slag field (including dump, mud) area, the construction site construction / temporary road area classification measure compensation.

\section{urban relocation compensation fee Estimated}

Urban relocation compensation investment include: compensation for urban residents relocation compensation, relocation compensation, relocation business unit.

\section{industrial and mining enterprises to deal with the estimated cost of compensation}

The industrial and mining enterprises investment compensation including housing and ancillary facilities and equipment facilities compensation compensation, relocation compensation, relocation compensation fee, production losses and infrastructure costs.

\section{professional project processing compensation cost estimates}

The compensation standards for professional projects and the compensation fees are calculated according to the plan and the corresponding compensation standards.

Professional project compensation costs include: highway, power transmission, telecommunications, broadcasting, cable television, pipelines, water conservancy facilities, cultural relics, etc..

\section{other expenses}

Other costs include preliminary work fees, survey planning and design fees, immigration management fees, technical training fees, supervision and assessment fees, consulting services, the implementation of agency fees. Respectively, according to the standard fee collection standards.

reserve

Including: basic preparation fee, spread preparation fee. The basic reserve fee shall be calculated according to the standard of charge for the feasibility study stage. 


\section{related taxes and fees}

The relevant taxes and fees refers to the land related taxes and fees, including farmland reclamation fees, farmland occupation tax, forest vegetation restoration fee.

\section{summary of immigrant compensation costs}

According to the investigation of the physical indicators, planning indicators and compensation standards, the calculation of resettlement compensation direct costs, other fees, preparatory fees, taxes and fees and summary.

a. rural resettlement compensation;

b. urban relocation compensation fee;

c. compensation for industrial enterprises;

d. professional project compensation;

e. other charges;

f. reserve;

g. related taxes and fees.

\section{schedule}

According to the project construction period and year, the relocation schedule and payment schedule to arrange the construction progress of the principle, formulate annual payment plan.

\section{Conclusion}

There are no specific standards and formats for resettlement projects, which should be consistent with the prevailing social, economic and living standards.

The resettlement project effect through resettlement actual situation and the anticipated goal of resettlement control, the implementation process, effectiveness and effect to carry out comprehensive and objective study, judge whether has achieved the anticipated target of resettlement, the resettlement plan is reasonable and effective resettlement; summarize the reasons for success or failure, learn from experience and lessons, provide technical support for the implementation of the follow-up work for the water Project; to explore more reasonable, to provide experience for the realization of scientific and standardized management of the resettlement work.

\section{References}

[1] Cernea, M Michael. Resettlement·Reconstruction·Development-Resettlement Policies and Experiences of World Bank. Hohai University Press, 1998:12-15

[2] Ravi Kanbur.Development Economics and the Compensation Principle [J] .International Social Science Journal,2003,(2).

[3] Shi Guoqing, Yuan Ruhua, analysis and evaluation method for the production and living standard of reservoir resettlement [J]. Journal of hydraulic engineering, 1996 (2)

[4] Jiao Aiping, research on the evaluation index system of production and living standard of resettlement of water conservancy project [J]. Journal of Yellow River Conservancy Technical Institute, 2006, (3)

\section{First Author:}

Rao Xiong, statistics and measurement technology professional,Graduate Students. 